\title{
Retfærdighed for ofre men ikke forsoning
}

\section{Vibeke Sperling}

\section{Udleveringen af Ratko Mladic er en milepæl for retfærdighed, men skærper også etniske splittelser ved at rippe op i gamle som nye sår. Og de invol- verede stater vægrer sig ved at tage de skridt, som reel forsoning kræver}

Serbiens udlevering af den krigsforbrydersigtede bosnisk-serbiske general Ratko Mladic til krigsforbryderdomstolen i Haag vil tjene retfærdighed for ofrene og deres efterladte og fremme afdækningen af sandheden om krigen i Bosnien-Hercegovina. Men det vil næppe bidrage til forsoning, hverken internt i Bosnien eller mellem Serbien og Bosnien endsige mellem Serbien og Kroatien.

Udleveringen til Krigsforbryderdomstolen for det tidligere Jugoslavien i Haag blev modtaget med stor glæde blandt bosniakkerne (muslimerne), der led de største tab under krigen 1992-95. Men det skabte vrede blandt de serbere, der ser Mladic som helt. Reaktionerne imod var dog stærkest i Republika Srpska, den serbiske del af Bosnien-Hercegovina. I Serbien var demonstrationerne overraskende afdæmpede, selv om nylige meningsmålinger havde vist, at 51 procent af serberne var imod udlevering af Mladic til Haag. Efter pågribelsen af Radovan Karadzic i 2008 udbrød der straks demonstrationer. Der gik flere dage, før der blev kaldt til demonstration i Beograd for Mladic, og de forløb mere fredeligt, selv om Mladic altid har været langt mere populær end Karadzic.

Og det lille flertal, som vendte sig imod udlevering af Mladic, ser næppe alle Mladic som helt. En stor del af dem mener, at serbernes lidelser under krigene i det tidligere Jugoslavien får for ringe opmærksomhed i forhold til ikke mindst bosniakker- 
nes lidelser. Den side af reaktionerne i Serbien bør tages alvorligt.

Om følelserne i Bosnien skrev Gojko Beric, kommentator for Sarajevo-avisen Oslobodjenje: "Dette er et delt land uden en eneste fælles sag, hvor dialog er umulig og et land, hvor hver side har sin sandhed om krigen".

Og således kan sagen Mladic ikke fremme forsoning i Bosnien.

\section{Serbiske følelser}

Den tidligere bosnisk-serbiske leder, Biljana Plavsic, leverede dog i et sjældent interview til det serbiske nyhedsmagasin NIN i juni et lille bidrag, da hun opfordrede Mladic til at erklære sig skyldig og tage sin straf: "Mladic bør påtage sig sin del af skylden ved FN's krigsforbryderdomstol og dermed rense det serbiske folk".

Men Plavsic frikender delvist Mladic for den værste forbrydelse, som han er anklaget for: massakren på omkring 8.000 bosniakkiske mænd og drenge i Srebrenica i 1995. "Jeg siger ikke, at han var skyldig i begivenhederne i Srebrenica, da nogen i det internationale samfund havde brug for den massakre", siger den nu 80-årige Plavsic. "Dengang vidste jeg ikke, hvad der skete i Srebrenica". På vej tilbage fra Bihac i det vestlige Bosnien så hun på $T V$, at Mladic udstedte ordrer i Srebrenica. "Jeg spurgte mig selv: Hvad er dog dette?"
Til spørgsmålet hvorfor hun som Republika Srpskas daværende præsident ikke spurgte Mladic selv, siger hun: "Jeg ved, hvad slags person Mladic er. Det var ikke muligt at ringe til ham og spørge: Hvad har du gjort?"

Plavsic afsonede selv seks år af en dom på 11 års fængsel for at have spillet en ledende rolle i forfølgelse af kroater og bosniakker under krigen i Bosnien 1992-1995. Hun blev løsladt før tid i 2009.

Plavsics indlæg i debatten om Mladic tæller særligt, da hun er den højst placerede i det tidligere Jugoslavien, som har taget ansvar for forbrydelser under krigene i regionen.

I interviewet påpeger hun korrekt, at Mladic må hjælpe serberne ud af anklagen for kollektiv skyld ved at vedkende sig sit personlige ansvar. Men hun bidrager også til myternes tågeslør i serbernes bevidsthed ved at gøre et katastrofalt svigt fra FN-styrkerne, der kunne have hindret massakren, til et udslag af at "nogle i det international samfund" ønskede, at den skulle ske.

Serbiens præsident Boris Tadic sagde, da Mladic blev pågrebet: "I dag lukker vi et vanskeligt kapitel i vort lands historie, som vil bringe os nærmere til fuld forsoning i regionen".

Umiddelbart skærpede det imidlertid kun de etniske konflikter, og Tadic begik den fejltagelse i mange serberes øjne primært at se det som et skridt nærmere EU-medlemskab. 
Han burde i stedet have fremhævet Mladics forbrydelser, så udleveringen kunne bidrage til større selvransagelse blandt serbere.

Og regeringens glade budskab til serberne om at de nu var kommet et syvmileskridt nærmere EU, troede de færreste serbere på. "EU finder bare på nye betingelser”, lød det som et omkvæd i Beograds gader i de dage.

\section{Veteraner lig udskud}

Et nødvendigt element i en forsoningsproces må være erkendelse af eget medansvar, men det viger Serbien tilbage for, når det gælder krigsforbrydelser i Bosnien. Krigsveteraner behandles reelt som udskud, fordi staten ikke vil kendes ved dem.

Denne skribent mødte flere veteraner, dagen før Mladic blev udleveret, blandt andre Ivan Kralj, serber opvokset i Bosnien, der meldte sig frivilligt til at slås for serberne $\mathrm{i}$ 1993.

Ivan kæmpede ved den serbiske enklave Krajina i Kroatien. Han mødte aldrig Ratko Mladic, men i stedet den notorisk brutale serbiske krigsherre Arkan, hvis deling kom Ivans til hjælp.

Om sin grund til at gå frivilligt $\mathrm{i}$ krig, siger Ivan: "Jeg havde fundet min bedstefars dagbog. Han var lokal leder for Titos partisaner under Anden Verdenskrig”. Bedstefaderen havde efter ordre fra Tito likvideret en deling cetnikker, royalistiske serbere, der også kæmpede imod nazisterne. "Jeg besluttede mig for at rette op på den historiske katastrofe, at serbere kæmpede mod serbere. Kroatiske fascister (de såkaldte Ustasja, der støttede nazisterne. Red.) havde nedbrændt vores landsby tre gange", fortæller Ivan.

Vi mødes på en cafe i Novi Sad i Serbiens nordlige provins Vojvodina, der i Serbien huser relativt flest serbiske flygtninge fra Kroatien, Bosnien og Kosova. Ivan fortæller: "Engang skulle vi igennem et mineret område, hvor flere af mine kammerater mistede ben og arme, andre livet en af de grufulde nætter. Mine medkæmpere gik i panik, en tog min riffel og stak af. Jeg stod tilbage med to granater, som jeg kastede imod kroaterne. De skreg vildt, for de troede, at vi alle var døde".

En anden nat gjorde den dengang 20-årige Ivans deling holdt under en kroatisk offensiv og ventede på mineryddere: "En minør, der havde sagt, at vi kun måtte gå i hans fodspor, trådte på en mine 20 meter fra mig og blev sprængt i stumper og stykker".

\section{Nej, nej ikke Srebrenica}

En veteran, hvorom det hed, at han havde deltaget i den Mladic-ledede massakre i Srebrenica, benægtede det, da vi mødtes: "Jeg var tæt på Srebrenica, men deltog ikke. Alligevel føler jeg dyb skam ved det, som 


\section{BAGGRUND}

jeg var med til, men Srebrenica, nej, nej", siger veteranen, der ikke vil citeres ved navn.

Ivan Kralj siger: "Skammen er vores evige følgesvend. Alle serbiske soldater, der ikke meldte sig for pengenes skyld eller for at plyndre, blev misbrugt. Jeg er aldrig kommet over det, og alle de veteraner jeg kender, går ned, kommer på fode og går ned igen".

Ivan startede på psykologistudier og fik hjælp af Center for Krigstraumer i Novi Sad, hvor han nu selv hjælper andre. Noget af det, som han finder mest meningsfyldt er at deltage i samtaler mellem unge og krigsveteraner: "De unge kan bedst uddannes imod krig af dem, som har været i krig".

På traumecentret, der har behandlet omkring 9.000 krigsveteraner, siger centerleder Milos Antic til spørgsmålet om de værste tilfælde: "Hver historie er værst. En som har været 24 timer i krig, kan have taget mere skade, end en soldat, der har været med i alle fem krige, Slovenien, Kroatien, Bosnien, Kosova og krigen med NATO i 1999".

Her i centret mærkes, at krigstraumer ikke kan generaliseres eller behandles som kollektivt fænomen. "Der er selvfølgelig den skillelinje, om man har været tæt på døden. Alt andet er personligt", siger Antic. Ingen af centrets veteraner har givet sig til kende om at have været i Srebrenica. "Der gemmer sig måske nogle her, men de værste forbrydere og mest traumatiserede er nok i Republika Srpska", siger Antic og fremhæver, at Novi Sad sikkert er den serbiske by, hvor flest har demonstreret imod udleveringen af Ratko Mladic til Haag. "Men blandt de omkring 20.000 demonstranter tror jeg ikke, at der var en eneste krigsveteran. Blandt 10.000 demonstranter i Banja Luka (Republika Srpskas hovedby) var der næsten kun krigsveteraner".

\section{Gamle sår åbnet}

Udleveringen af Ratko Mladic åbnede gamle sår fra krigene i 1990'erne og endnu ældre. Mange serbere begyndte igen at tale om kroatiske nazister, Ustasjas forbrydelser imod serbere. I juni talte Serbiens præsident Tadic for at udvikle en politik for erindring om de forbrydelser, som sydslaviske folk har begået imod hinanden. En politik, som ikke vil dele kroater, bosniere og serbere, men i stedet forene dem, understregede han.

Men det var ikke Mladics forbrydelser som massakren i Srebrenica, som fik Tadic til at love en sådan politik.

Det var under en mindehøjtidelighed i landsbyen Jadovno i Kroatien for 70-året for likvideringen af omkring 40.000, heraf 38.000 serbere, i de Ustasja-ledede koncentrationslejre, den største Jasenovac og næststørste Jadovno, fra maj til august 1941. For serberne synes det ofte 
endnu tættere på end 1990'ernes forbrydelser.

Tadic havde tidligere sammen med Kroatiens præsident Ivo Josipovic været i Vukovar i Kroatien for at mindes krigens ofre der. Det var et stort skridt til officiel forsoning. Josipovic glimrede ved sit fravær i Jadovno, men sendte dog en repræsentant. Både serbiske og kroatiske medier har i år skrevet om forværring af relationerne igen, og Tadic blev væk fra fejring af 20 årsdagen for Kroatiens selvstændighed. Ifølge serbiske medier fordi hans tilstedeværelser ville ophidse serbere, der forbinder Kroatiens kamp for frihed i 1991 med forbrydelser imod serbere. Ikke mindst den blodige uddrivelse af serbere fra det tidligere serbisk dominerede Krajina i Kroatien.

Serbere kan have ret i, at Ustasjas forbrydelser har fået for ringe omtale af vestlige medier og politikere. Men det ville klæde Serbien også at sætte fokus på tidligere præsident Slobodan Milosevics opildnelse af den nationalisme, som udløste krigene i 1990'erne. Serbisk tv kørte dengang billeder fra verdenskrigens kroatiske koncentrationslejre i båndsløjfer og skabte en stemning af, at hvis serbere ikke slog kroater og bosniakker ihjel, ville de selv blive udslettet. Den samme logik ligger bag, at mange serbere stadig ser Mladic som en helt, der frelste serbere. Og der mangler nogle på anklagebænken i Haag: serbiske redaktører, journalister og intellektuelle, der skabte stemningen af, at efterkommere af ofrene for Ustasja under Anden Verdenskrig måtte blive bødler for at redde eget folk.

\section{Begges myter}

Den side af Milosevics regime vil dagens Serbien ikke vedkende sig. Det er en af de myter, som forhindrer forsoning i regionen. Det samme gør de kroatiske myter, at nutidens Kroatien ikke har noget at gøre med det nazistiske Kroatien.

Den kroatiske præsidents udsending til ceremonien i Jadovno, parlamentsmedlem Vesna Pusic, understregede, at grundlaget for Kroatien i dag er demokrati og antifascisme. Dagens Serbien frakender sig ansvar for Milosevics forbrydelse imod kroatere, og dagens Kroatien frakender sig ansvar for Ustasjas forbrydelser og ideologi, som i vidt omfang blev videreført af præsident Franjo Tudjman, der med sin nationalisme delte ansvaret for krigene i begyndelsen af 1990'erne med Milosevic.

Bevægelsen 'Jadovno 1941' mener, at Kroatien derfor undlader at efterforske det nøjagtige antal ofre for Ustasja-regimet og at markere stederne for dets forbrydelser imod serbere.

Boris Tadic fremhæuede i sin tale $\mathrm{i}$ Jadovno grumme eksempler på fortidens spøgelser ved blandt andet nutidens sportsbegivenheder. Kroatiske sportsentusiaster råber "Dræb 
serbere!" og serbiske råber "Kniv, pigtråd, Srebrenica!" imod bosniakker.

Fornærmende og truende paroler under kampe imellem rivaliserende sportshold hører til dagens orden i det tidligere Jugoslavien. Og det er især tilfældet under kampe imellem kroatiske og serbiske hold.

Tadic sagde, at det var meget svært for ham at komme til Jadovno for første gang nogensinde, fordi hans bedstefar og onkel blev myrdet $\mathrm{i}$ koncentrationslejren ved landsbyen. "Jeg er her med min mor, men hendes søster, min tante kunne ikke finde styrke til at komme", sagde han.

Men realisering af hans "erindringens politik' kræver, at Serbien og Kroatien finder styrke til at tale åbent om deres staters medansvar. Det venter regionen og omverdenen stadig på.

Fint at Tadic mindes ofre for også Anden Verdenskrig. Men reel forsoning er umulig uden alles erkendelse af deres moderne staters medskyld. For EU, som er parat til at optage Kroatien og mere velvillig over for Serbien efter udlevering af Ratko Mladic, er der næppe nogen vigtigere opgave i regionen end at bidrage til udvikling af fælles ansvarlighed for regionens blodige historie.

De bosnisk-serbiske krigsveteraner fortæller, at de kommer bedst ud af det med andre veteraner på tværs af etniske skel. Men det gælder primært med muslimske veteraner. De har meget sværere ved at tale med kroatiske veteraner, fordi de kun ser sig som tidligere forsvarere af deres land imod en serbisk angrebsmagt, fortæller de.

Kroatiens regeringschef Jadranka Kosor erklærede, da Mladic blev pågrebet: "Som offer for aggression, hylder Kroatien pågribelsen af Ratko Mladic". Kroatiens opfattelse af sig selv som kun offer er en af mange nationale myter, som plager regionen og forhindrer forsoning.

Retssagen imod Mladic vil sandsynligvis ikke rokke ved de etablerede myter i regionen. Det kan formentlig først ske, når de tidligere krigsførende lande selv gennemfører krigsforbrydersager imod de mindre fisk, som stadig går frit omkring og lever normalt trods deres forbrydelser under krigen. Der bør formentlig også en lokal Sandhedsog Forsoningskommission til. Et tidligt serbisk forsøg på at etablere en sådan i 2003 brød sammen i uenigheder om mandatet.

\section{Serbiens EU-optimisme}

De store smil er fremme hos Serbiens viceregeringschef Bozidar Djelic i regeringsbygningen i Beograd. Han er nu i sikkerhed imod det tidligere evigt pinagtige spørgsmål: hvorfor er Mladic ikke fanget. "Vi kan koncentrere os om fremtiden, efter at Mladic er bragt til Haag", siger Djelic, der har ansvar for Serbiens integration i EU. Serbien krævede straks efter pågribelsen af Mla- 
dic, at EU sætter en dato for start på forhandlinger om Serbiens optagelse i EU. Er det ikke for optimistisk?

"Man kan jo ikke være sikker i dagens Europa. Vi ved, at vi skal gennemføre mange reformer for at stå så stærkt som muligt, men en dato er nødvendig for at holde Serbien på EU's dagsorden”.

Til det forhold, at det er en udbredt opfattelse i Serbien, at Mladic kun blev pågrebet efter pres fra $\mathrm{EU}$, siger Djelic:

"Det må gøres mere klart, at vi ikke ser det som et element i Serbiens integration i EU, men som udtryk for vores respekt for folkeret og retfærdighed".

Men hvorfor er myten om Mladic ikke slået ihjel, når Serbiens ledere har haft 16 år til det?

"Vi må informere bedre om Mladics konkrete forbrydelser. Men folkestemningen i Serbien er præget af, at omverdenen ikke taler om de mange uskyldige serbere, der også blev slået ihjel. Bitterheden over det er skærpet af Mladic-sagen. Retfærdigheden fremstår som selektiv for serbere".

Blandt de mange teorier om, hvorfor Mladic ikke blev fanget tidligere, er at han kan vidne om den serbiske stats medskyld for massakren i Srebrenica. Mladic var højtstående officer på den serbiske hærs lønningsliste, så hvordan kan Beograd hævde, at Serbien ikke var medskyldig i hans forbrydelser?

"Også Bosnien erkender nu, at
Serbien ikke var medskyldig i massakren i Srebrenica. Vores parlament vedtog sidste år en fordømmelse af massakren, og Tadic har været i Srebrenica to gange for at undskylde".

Og Serbien henholder sig til, at den Internationale Straffedomstol (ICC) har kendt Serbien skyldig for ikke at gøre nok for at forhindre blodbad, herunder massakren i Srebrenica, men har frikendt Serbien for aktivt medansvar.

\section{Srebrenica fortabt}

Den bosniakiske borgmesteren i Srebrenica, Camil Durakovic, håber at pågribelsen af Mladic vil medføre, at Serbien må vedgå sit medansvar.

"Vores håb er nu, at krigsforbryderdomstolen i Haag drager den konklusion, at Serbien var medskyldig. Alle må erkende, at Serbien var direkte involveret $\mathrm{i}$ alt, som skete i det tidligere Jugoslavien. Kun ved at identificere de involverede institutioner kan vi overvinde dem og komme videre". Men her må domstolen i Haag skuffe borgmesteren, da den kun kan dømme enkeltpersoner - ikke stater.

Durakovic fortæller, at der har været meget stille i Srebrenica, siden Mladic blev arresteret. "Her har ikke været en eneste demonstration. Byens serbere er skamfulde og går sjældent ud i disse dage. Men forsoning handler nu om økonomi, der knytter folk sammen, som alle nok 
reelt ønsker”. Borgmesteren fortæller, at der nok er verbale sammenstød imellem byens serbere og bosniakker, ikke fysiske. "Men vi bosniakker er reelt uønskede i Srebrenica, som jo er del af Republika Srpska”.

Før krigen havde Srebrenica 37.000 indbyggere, heraf 28.000 bosniakker, resten serbere og enkelte kroater. Nu er her lidt over 7.000 indbyggere, over 4.000 heraf er serbere. Durakovic blev sikret valg, da også flygtninge har stemmeret. "Men det er en midlertidig ordning. Når den stopper, bliver vi bosniakker stemt ud".

Der er mange tillukkede huse i Srebrenica, ejet af bosniakker, som af følelsesmæssig grunde ikke vil sælge dem, men tøver med at vende tilbage.

Durakovic tegner en cirkel med en streg igennem: "50 procent af flygtningene er for bange til at vende hjem. 20 procent er integrerede andre steder og vender aldrig hjem, resten vil gerne, men deres huse er ikke genopbygget og de kan ikke få arbejde". Af 6.250 ødelagte huse er kun 2.000 genopbygget, den internationale hjælp er dalet markant, og Republika Srpska blokerer for jobskabelse som fx et større sundhedscenter, som borgmesteren viser tegninger til på sin væg.

Ifølge Durakovic diskrimineres bosniakkerne, centraladministrationen i Banja Luka favoriserer byens serbere.
Den arbejdsløse serber Miodrag siger: "De fleste af byens serbere går stille med, at de nok støtter Mladic. Jeg ser ham som en grusom forbryder, men begrebet folkemord misbruges om Srebrenica. Folkemord er likvidering af også alle kvinder og børn, som Hitler gjorde".

Miodrag gik i sjette klasse, da bosniakkerne stemte for selvstændighed, og krigen brød ud: "Jeg husker afstemningsdagen, for der var stemmested i vores nabohus. Lige efter var vi i totterne på hinanden i klassen, selv om muslimske og serbiske børn ikke havde kendt forskel på hinanden få dage forinden".

\section{Mladic i batterifabrikken}

Menja Djokaz mødte Mladic 'derovre', fortæller hun og peger på en fabriksbygning på den anden siden af vejen ved mindeparken for ofrene i Srebrenica lidt uden for byen. "Det var en batterifabrik, hvor hollandske FN-styrker bragte os hen, da vi var fanget her i dalen af serbisk ild. General Mladic kom så tæt på mig, som du er nu, og sagde med sit rævesmil, at han ville få os i sikkerhed".

Srebrenica var den fjerde rigeste by i Bosnien før krigen, da området er rigt på mineraler, men den står nu arret tilbage. Den skinnende sol gør ikke det trøstesløse indtryk mindre. Et uendeligt trist sted, omkranset af betagende smukke bjerge. Det er ikke de stadig ødelagte huse, som skæmmer mest, men de mærkbare 
sjælelige sår. En by forkrampet af en smerte, som ikke vil gå væk.

Blandt de ubehagelige spørgsmål for Serbien er, hvorfor det tog så lang tid at fange Mladic, selv efter at den politiske vilje skulle være til stede. Blandt andet i betragtning af hans dårlige helbred i de seneste år og af at han skal have besøgt serbiske hospitaler, er det svært at tro, at serbiske myndigheder ikke kendte til hans færden.

Serbiens regering viste mod, da den pågreb ham, $\mathrm{i}$ betragtning af at den væsentligste grund til at tidligere ministerpræsident Zoran Djindjic blev myrdet i 2003 var, at han udleverede Slobodan Milosevic til Haag. Djindjic tog på sin vis samarbejdet med Haag mere alvorligt end Tadic. Djindjic opfattede det ikke som bare en forpligtelse at udleverede krigsforbrydere, men han mente, at det var i Serbiens interesse at bryde med den voldelige fortid og den kultur af straffrihed for kriminalitet, som den historie havde skabt.

Djindjic bombarderede bevidst serberne med sandhed om krigene for at få dem til at vedkende sig og bearbejde historien. Tadic og den $\varnothing$ vrige nuværende ledelse er mindre tilbøjelig til at dvæle ved fortiden og har tilsyneladende altid været mest interesseret i Mladic som bytteobjekt til at fremme Serbiens interesser internationalt og især med henblik på EU-medlemskab.

Til spørgsmålet hvad regeringen gør for at fremme forsoning, siger viceregeringschef Bozidar Djelic: "Nationalt tv har bragt mange dokumentarfilm om forbrydelserne, og mange vil nu følge for at få fokus på kontakt til den enkelte borger, også i nabolandene”. Pågribelsen af Mladic gør det muligt for regeringen nu at intensivere arbejdet for forsoning med naboerne, siger Djelic, der godt ved, at der er langt igen. "Min generation er den sidste, der har et net af venner i de andre lande i det tidligere Jugoslavien", siger den 45årige Djelic. "Vore børn må have det bedste tilbage fra Titos Jugoslavien. Serbien har gjort sit for alle uskyldige ofre. Vi skal ikke have en ny runde af had".

Om EU siger Djelic: "Serbien er tilbage i en klassisk form for integrationsproces efter udleveringen af Mladic".

Også den udbredte korruption kan bedre bekæmpes, nu hvor Mladic er i Haag, understreger Djelic: "Vi har arresteret mange også fra regeringspartier for korruption, og efter at jagten på Mladic er succesrigt afsluttet, kan samtlige sikkerhedstjenestens kræfter gå til bekæmpelse af organiseret kriminalitet og korruption".

\section{Mod til at vende tilbage}

I Srebrenica er Dzelaludina Pasic blandt dem, "der har fundet mod til at vende tilbage", fordi hun mener, at hun skylder sin far og andre ofre for massakren i 1995 at leve, hvor de 
døde. Hun gik i femte klasse dengang og har skrevet om batterifabrikken: "Vi tilbragte natten i batterifabrikken. 11. juli siger FN-soldater, at vi skal til Tuzla. Far står i anden række ved vejen og vi stiger på bussen. Han siger, at alt bliver godt, men hans øjne fortæller noget andet. Jeg græder og skriger, men min far bliver". Hun ser ham aldrig igen.

I Beograd kæmper Center for Kulturel Afgiftning, der har eksisteret siden Milosevics tid, for forsoning ved hjælp af oplysning om forbrydelserne gennem udstillinger, teaterforestillinger og film om krigene i det tidligere Jugoslavien. Centerleder, teaterinstruktør Borka Privicevic, siger: "Udleveringen af Mladic kan kun medvirke til forsoning, hvis erkendelse af serbisk medskyld påtvinges borgerne ovenfra som i Tyskland efter nazismen. Det har vi endnu ikke set tegn på fra vores regering, som prioriterer ønsket om EUmedlemskab over den vigtigste opgave: at rense det serbiske samfund ved at se svinehunden direkte i øjnene".

\section{Retsopgør og forsoning}

Massakren i Srebrenica i 1995 er kaldt den værste krigsforbrydelse i Europa siden Anden Verdenskrig. Folkedrabet i Rwanda i 1994 overskygger Srebrenica som en af de største menneskelige tragedier siden Holocaust med mellem en halv og en hel million dødsofre.
Både i Rwanda og Bosnien var det forbrydelser af et omfang, der i sig selv gør forsoning mere end svær. Og kan retsopgør bidrage til forsoning? Frederik Harhoff, dommer ved Krigsforbryderdomstolen for det tidligere Jugoslavien, mener, at domstolens bidrag til forsoning i regionen er "begrænset, fordi domstolen hverken har haft mandat eller midler til at bidrage konkret til forsoning på det lokale plan. Men på det overordnede plan har domstolen ydet en vis retfærdighed, fordi ofrenes lidelser er blevet hørt og anerkendt i det internationale retssystem".

Forsoning må ske lokalt, siger Harhoff: "Vi kan blotlægge en del af sandheden så konkret, som det nu er muligt i en straffesag, hvor der i sagens natur altid vil være meget, der ikke bliver sagt. Vi kan fastslå, hvem der begik forbrydelserne, og vi kan sætte navne på nogle af ofrene og omstændighederne, som har stor betydning for de efterladte. Men konkret forsoning kræver en målrettet indsats i lokalområder”.

Harhoff nævner et stjerneeksempel fra en lille landsby i Bosnien med 20 serbiske familier på den ene side og 20 muslimske på den anden side af den lille å. Efter krigen var der ingen kontakt over vandløbet, indtil en gæv kone sagde "Nu kan det være nok" og gik over åen for at spørge, om der var noget, hun skulle købe med, nu hun alligevel skulle til byen. 
"Det er først, når den ene part rækker hånden frem, at der skabes bevægelse i lokalsamfundet", siger Harhoff, der mener at forsoningsprocessen i Rwanda "er noget længere fremme". Men det er efter hans opfattelse ikke så meget i kraft af den internationale domstol for Rwanda, "men snarere, at der eksisterer et net af lokale domstole, de såkaldt gacaca-domstole, hvor landsbyens ældre og kloge sætter sig sammen på torvet og afgør konflikter”.

Disse lokale domstole har behandlet over 1,2 millioner sager i et land, hvor de fleste dommere og advokater enten var dræbt eller flygtet. Der findes derimod kun et centraliseret domstolssystem for krigsforbrydersager i det tidligere Jugoslavien. $\mathrm{Og}$ krigsforbryderdomstolen for Rwanda har i et vist omfang kunnet give erstatning, bl.a. til genopbygning af huse, "som vi ingen ressourcer har til her i Haag", siger Harhoff.

I det tidligere Jugoslavien høres ofte, at forsoning ikke er mulig, medmindre alle skyldige pågribes, så efterladte ikke skal risikere at møde dem på gaden.

Frederik Harhoff siger, at det er en illusion: "Forsoning handler jo netop om, at folk skal kunne møde hinanden igen med oprejst pande. Derfor er det ikke nok bare at bure alle gerningsmændene inde. Forsoning er en mental proces, der handler om komme videre i livet. I øvrigt har der fra starten været en arbejdsdeling, så kun de mest overordnede gerningsmænd skulle retsforfølges at FN-domstolen i Haag, resten lokalt".

Efter udleveringen af Ratko Mladic til Haag står konflikten om Kosova tilbage som den største politiske forhindring for serbisk EU-medlemskab. At Kroatien nu er accepteret som parat, kan fremme Serbiens sag. Kosova trækker den anden vej. Serbien henholder sig til, at flere EU-medlemmer ikke anerkender Kosova, så det ikke kan stilles som betingelse, at Serbien gør. Men Serbien har fået tilstrækkelige vink med vognstænger fra de store i EU til at det må vide, at fuld normalisering af forholdet mellem Serbien og Kosova er en betingelse for, at nogen af dem kommer i EU - Ratko Mladic eller ej.

Vibeke Sperling er udenrigsmedarbejder ved Politiken og redaktør af Udenrigs. 